\title{
Ishak Score 1
}

National Cancer Institute

\section{Source}

National Cancer Institute. Ishak Score 1. NCI Thesaurus. Code C95151.

Minimal fibrosis in some portal areas. 